\title{
BETA-ADRENERGIC BLOCKING AGENTS AND ANAESTHESIA: A REVIEW
}

\author{
WILLIS A. WARNER, M.D.*
}

RECENT DEvelopMENTs in physiological and pharmacological studies involving the autonomic nervous system have uncovered intriguing new dimensions. It appears that clinical medicine will be influenced significantly by these discoveries. Diverse pathological entities such as angina pectoris, ${ }^{1-9}$ cardiac arrhythmias ${ }^{1,3,10-18}$ obstructive cardiomyopathies, ${ }^{11,19,20}$ phaeochromocytoma, ${ }^{3,21-23}$ and essential hypertension ${ }^{24,25}$ are some likely areas where therapeutic benefits may be realized.

Anaesthesia and the autonomic nervous system are interrelated to a profound degree. Brewster's demonstration ${ }^{26}$ of the deleterious effects of ether in the absence of sympathetic integrity is an illuminating example. Correlation of depth of cyclopropane and ether anaesthesia with plasma catecholamine levels by Price ${ }^{2 \tau}$ was another milestone in understanding anaesthetic impact on the sympathetic nervous system. These two examples point out the need for the anaesthesiologist's appreciation and knowledge concerning interrelationships between anaesthesia and the autonomic nervous system.

The objective of this review is to examine what we presently know about beta-adrenergic blockade, and its influence upon anaesthesiology. Readers wishing to pursue other facets of beta-adrenergic blockade should consult a recent review by Epstein and Braunwald. ${ }^{20}$

\section{Basic Pharmacology of Beta-Adrenergic Blocking Agents}

Initial insights into the action of epinephrine were reported by Langley in $1905 .^{2 \mathrm{~S}} \mathrm{He}$ postulated that effects of epinephrine could be separated into excitatory and inhibitory mechanisms which were dependent upon receptor substances. Shortly thereafter $\mathrm{Dale}^{29}$ demonstrated that ergot alkaloids were capable of reversing some excitatory effects of epinephrine, without influencing inhibitory manifestations.

A milestone in understanding adrenergic mechanisms was the introduction of Ahlquist's concept $t^{30}$ that effector sites could be separated into excitatory (alpha) and inhibitory (beta) receptors, on the basis of response to sympathomimetic amines. It should be remembered that these receptors are a conceptual convenience, and as yet have not been identified in actuality. Inability to demonstrate them histologically suggests they are biochemical, possible enzymatic, in nature. Various effects of alpha and beta stimulation are presented in Table I.

Although stimulation of beta receptors can be generally classified as being

-Assistant Professor of Anesthesiology, University of Florida College of Medicine, Gainesville, Florida. 
TABLE I

\begin{tabular}{|c|c|c|}
\hline Effector organ & Receptor type & Effect \\
\hline \multicolumn{3}{|l|}{ Heart } \\
\hline SA node & $\beta$ & increase in heart rate \\
\hline AV node & $\beta$ & $\begin{array}{l}\text { increase in conduction velocity } \\
\text { and shortening of functional } \\
\text { refractory period }\end{array}$ \\
\hline atria & $\beta$ & increase in contractility \\
\hline ventricles & $\beta$ & increase in contractility \\
\hline \multicolumn{3}{|l|}{ Smooth muscle } \\
\hline blood vessels to skeletal muscle & $\begin{array}{l}\alpha \\
\beta\end{array}$ & $\begin{array}{l}\text { constriction } \\
\text { dilatation }\end{array}$ \\
\hline $\begin{array}{l}\text { blood vessels to skin and mucosa } \\
\text { bronchial muscle }\end{array}$ & $\alpha$ & $\begin{array}{l}\text { constriction } \\
\text { relaxation (dilatation) }\end{array}$ \\
\hline \multicolumn{3}{|l|}{ Eye } \\
\hline $\begin{array}{l}\text { radial muscle; iris } \\
\text { ciliary muscle }\end{array}$ & $\begin{array}{l}\alpha \\
\beta\end{array}$ & $\begin{array}{l}\text { contraction (mydriasis) } \\
\text { relaxation (negative } \\
\text { accommodation) }\end{array}$ \\
\hline \multicolumn{3}{|l|}{ Gastro-intestinal tract } \\
\hline $\begin{array}{l}\text { stomach } \\
\text { intestine }\end{array}$ & $\begin{array}{c}\beta \\
\alpha \text { and } \beta\end{array}$ & $\begin{array}{l}\text { decrease } \\
\text { decrease }\end{array}$ \\
\hline \multicolumn{3}{|l|}{ Sphincters } \\
\hline stomach & $\alpha$ & contraction \\
\hline \multicolumn{3}{|l|}{ Urinary bladder } \\
\hline $\begin{array}{l}\text { trigone and sphincter } \\
\text { detrusor }\end{array}$ & $\stackrel{\alpha}{\beta}$ & $\begin{array}{l}\text { contraction } \\
\text { relaxation }\end{array}$ \\
\hline
\end{tabular}

inhibitory, e.g. vasodilatation and bronchodilation, notable exceptions exist. Cardiac stimulatory effects appear to be beta mediated, and those sympathomimetic amines which stimulate beta receptors will produce an increase in heart rate (positive chronotropic effect) and myocardial contractility (positive inotropic effect).

Within this framework sympathomimetic amines can be generally classified as being predominantly alpha or beta stimulators. Rigid categorization is difficult because some sympathomimetic amines have both alpha and beta effects. Epinephrine, for example, produces positive chronotropic and inotropic effects (beta receptors) and also vasoconstriction in some vascular beds and excitation of the uterus (alpha receptors).

Epinephrine-induced activation of phosphorylase or glycogenolysis in the heart and skeletal muscle is inhibited by beta blockers, whereas alpha blockers exert no effect, indicating it is beta receptor mediated. So far, other metabolic effects of catecholamines, such as free fatty acid mobilization and hepatic glycogenolysis, have escaped inclusion within the alpha-beta classification. ${ }^{20}$ This is partly because of widespread species variability in response patterns. ${ }^{20}$ Still other receptor mechanisms may mediate these metabolic effects. ${ }^{32,45}$

This concept of alpha and beta-adrenergic receptors has been most useful in delineating the effects of various drugs. Identification of agonist drugs which stimulate alpha or beta receptors, and antagonists, which block the receptors, has been possible. Isoproterenol for example, is an almost pure beta stimulator, whereas an analogue, dichloroisoproterenol (DCI), antagonizes the effects of isoproterenol, and can be classified as a beta blocker. ${ }^{32}$ 
Using this classification, drugs affecting the sympathetic nervous system can be separated into four functional categories: (1) alpha receptor stimulators, or agonists (example: phenylephrine); (2) alpha receptor blockers, or antagonists (example: phenoxybenzamine); (3) beta receptor stimulators, or agonists (example: isoproterenol); (4) beta receptor blockers, or antagonists (example: propranolol). Not until DCI was synthesized was actual beta blockade demonstrated. ${ }^{33}$ DCI has some slight sympathomimetic action itself, ${ }^{34}$ however, so it is not a pure blocker.

In 1962 pronethalol was introduced ${ }^{2,35}$ and unlike DCI did not stimulate the heart. A spate of studies using pronethalol was sharply curtailed when the drug was shown to produce thymic tumours in mice. ${ }^{36}$

Black et al. ${ }^{37}$ then introduced propranolol, believing it satisfied the following criteria: (1) specific blockade of adrenergic beta receptors, (2) freedom from sympathomimetic activity, (3) increased activity over pronethalol with no increase in toxicity, and (4) absence of carcinogenesis in mice. ${ }^{38}$ Propranolol appears to be about ten times as potent as pronethalol. ${ }^{37}$

Structural relationships between isoproterenol, DCI, pronethalol, and propranolol are shown in Figure 1. It can be seen that beta receptor agonists and antagonists are closely related chemically. Alterations in the ring structure seem to determine whether a compound in this group stimulates or blocks beta-adrenergic receptors. ${ }^{30}$

Pronethalol and propranolol abolish the tachycardia and vasodepressor response produced by isoproterenol in anaesthetized cats. ${ }^{35,37,38}$ Propranolol blocks the tachycardia produced by stellate ganglion stimulation in anaesthetized cats, whereas bradycardia secondary to vagus nerve stimulation is not affected. ${ }^{38}$<smiles>[R]OC(=O)N[R20]#N</smiles><smiles>CC(C)NCC(O)Cc1ccc(Cl)c(Cl)c1</smiles><smiles>CNCC(O)c1ccc(O)c(O)c1</smiles><smiles>CCCCCCCNC(C)C</smiles><smiles>[R6]Oc1c(OCC(O)CNC(C)C)ccc2ccccc12</smiles>

FIGURE 1. Structural formulae of adrenergic agonists and antagonists. 
Experiments by Shanks et al. ${ }^{38,40}$ on anaesthetized dogs (open chest) revealed a reduction in resting arterial rate, arterial pressure, cardiac contractile force, and ascending aortic flow following propranolol administration. Reserpinized dogs given propranolol showed no change in heart rate, arterial pressure, or cardiac contractility. These results suggest that the negative inotropic and chronotropic actions of propranolol in normal dogs result from block of resting sympathetic tone. Flacke et al. ${ }^{41}$ studied haemodynamic effects of propranolol in anaesthetized dogs after sympathetic (epidural) and parasympathetic (atropine) block. They concluded that propranolol had no direct depressant effect on the heart in doses of less than $3 \mathrm{mg} . / \mathrm{kg}$., in the absence of reflex activity.

Beta blockade produced by propranolol is a competitive type block. Complete break-through can be achieved by adding a beta-agonist, for example, isoproterenol. ${ }^{42,43}$ Repetitive administration of isoproterenol in the propranolol-treated animal indicates the half-life of propranolol to be in the range of $40-50$ minutes. ${ }^{44}$

A striking feature of the newer beta-adrenergic blocking drugs is their high degree of specificity. They do not antagonize positive inotropic effects of calcium, xanthines, or cardiac glycosides, nor do they block vasodilatation produced by histamine, nitroglycerin, or acetylcholine. ${ }^{20,31,45}$

\section{Cardovascular Effects of Beta-Adrenergic Blockade}

Inquiry into altered haemodynamics during beta-blockade in resting supine subjects has evoked conflicting answers. Sowton and Hamer ${ }^{46}$ reported a 20 per cent reduction in cardiac output in the resting subject; stroke volume decreased 15 per cent and heart rate declined 10 per cent. Their subjects had mild left ventricular disease, however, which may have been a significant factor.

The same investigators observed that beta blockade caused a 30 per cent reduction in cardiac output among patients with complete heart block on artificial pacemakers at a fixed rate. This would indicate a significant negative inotropic effect existed during beta blockade in these patients.

Haemodynamic studies by Sonnenblick et $a l_{.}{ }^{47}$ in resting supine subjects did not show these changes; no alteration in ventricular dimensions was discernible, as determined by myocardial force-velocity relationships. According to Chamberlain, ${ }^{48}$ on the other hand, pronethalol increased heart size before and during exercise.

It appears that sympathetic tone is minimal in the resting supine subject but assumes increasing importance with demands imposed by exercise. ${ }^{47,49}$ Most studies of the exercising subject indicate that beta-adrenergic blockade produces deterioration of cardiac performance. ${ }^{20,46,47,50,51}$ Exercise tolerance was reduced 40 per cent by beta-adrenergic blockade in subjects investigated by Epstein et al. ${ }^{50}$ Haemodynamic observations in these subjects during maximal exercise revealed a 22 per cent reduction in cardiac output; mean arterial pressure declined by 15 per cent, and left ventricular minute work decreased 34 per cent.

Slight to moderate degrees of decreased arterial blood pressure have been reported, as a consequence of beta-adrenergic blockade. ${ }^{24,25}$ The decrease in 
blood pressure may be a direct effect of reduced cardiac output, with ultimate resetting of baro-receptor responsiveness. ${ }^{25}$ Propranolol has no direct effect on peripheral vessels; a study of forearm blood flow showed no change in resting flow. ${ }^{52}$ It does abolish the vasodilator effects of beta stimulation with isoproterenol, and converts the biphasic response of epinephrine into a vasoconstrictor response. ${ }^{38,52}$ Vasoconstrictive effects of norepinephrine (an alpha effect) are not affected by propranolol, as would be expected of pure beta receptor blockade.

Beta-adrenergic blocking drugs show considerable promise in the treatment of various cardiac arrhythmias. ${ }^{1,3: 10-18}$ Abolition of digitalis-induced arrhythmias has been especially successful. Among the nondigitalis arrhythmias, best results have been achieved in the treatment of atrial fibrillation and atrial flutter; ${ }^{20}$ a decrease in ventricular rate has been an almost uniform observation. ${ }^{12,15}$

Applicability to non-digitalis-induced ventricular arrhythmias has not been as impressive as with supraventricular or digitalis-induced arrhythmias. Nevertheless, premature ventricular contractions, ${ }^{15,16}$ ventricular tachycardia, ${ }^{16}$ and ventricular fibrillation $^{13}$ have been reported to respond to propranolol. Beta blockers have been employed effectively to reverse arrhythmias associated with anaesthesia, ${ }^{1, \overline{1} 3-58}$ particularly with cyclopropane and halothane (see part III).

One of the most exciting possibilities of beta-adrenergic blockade is in the management of acute myocardial infarctions. Cardiac arrhythmias are responsible for a large segment of coronary deaths, and prevention of lethal arrhythmias can be expected to significantly improve survival in acute myocardial infarction. In a recent study in which alternate patients with myocardial infarction received propranolol, the mortality rate was 16 per cent versus 35 per cent in the control group. ${ }^{59} \mathrm{~A}$ subsequent multicentre study failed to show any difference in survival rates between control and propranolol treated groups. ${ }^{60}$ Seriously ill patients were excluded from the study; possibly these were the patients most in need of beta blockade.

Inquiry into the mechanism of anti-arrhythmic properties of these drugs elicits complex answers. ${ }^{61-64}$ Certainly the anti-arrhythmic action is not a pure inhibition of adrenergic stimulation as initially believed. It now appears that pronethalol and propranolol have a dual anti-arrhythmic effect: (1) beta-adrenergic blockade, and (2) a quinidine-like effect-increasing the refractory period, and decreasing excitability, conduction velocity, rate of rise of action potential, and the "overshoot" potential. ${ }^{62,64,65}$ Other experimental compounds like MJ 1999 appear to operate more in the realm of pure beta blockade, i.e. they block catecholamineinduced arrhythmias but not digitalis-induced arrhythmias. ${ }^{20}$

Preoperative preparation of phaeochromocytoma patients with alpha-adrenergic blocking agents (phentolamine, phenoxybenzamine) is based on the rationale that vasoconstriction is ablated and circulating blood volume will expand. These drugs, however, provide no direct anti-arrhythmic protection except in relatively large doses. ${ }^{66}$ Beta-adrenergic blocking drugs have been reported to be of value in controlling arrhythmias resulting from catecholamine stimulation in the preoperative period, ${ }^{3,21,22}$ during surgery, and in the inoperable patient ${ }^{23}$ with phaeochromocytoma.

Many reports attest to therapeutic benefits produced by propranolol in the 
treatment of angina pectoris. ${ }^{1-9}$ Just why it is beneficial is not clear. The most likely explanation is that beta-adrenergic blockade reduces myocardial oxygen requirements. ${ }^{9}$ While adrenergic mechanisms in the coronary circulation are still poorly defined, there is considerable evidence that sympathetic stimulation produces an increase in myocardial oxygen consumption which outpaces the increase in coronary blood flow. ${ }^{67}$ To say it in another way, catecholamines provide emergency service (increased myocardial work) at a higher cost (oxygen consumption in excess of blood flow). The anginal patient can ill afford the added cost and apparently benefits from the reduction in myocardial oxygen consumption which exists during beta-adrenergic blockade.

As pointed out by Epstein and Braunwald, ${ }^{20}$ beta-adrenergic blocking agents may alter myocardial oxygen requirements in various ways. Thus, lessened oxygen requirements would result from the reduction in heart rate, arterial blood pressure, velocity of conduction, and also decreased shortening of myocardial fibre length. Conversely-and perhaps adversely-myocardial oxygen requirements are heightened by the increase in systolic ejection time and ventricular dimensions which occur during exercise. Whether or not benefit accrues to the patient depends upon the balance of these opposing forces.

More evidence that beta blockade is not wholly beneficial was presented by Parratt and Grayson. ${ }^{68}$ Measuring myocardial blood flow in dogs by means of a thermocouple technique, they reported a 34 per cent reduction following propranolol administration. Only part of this reduction in flow was ascribed to lowered cardiac work, the rest to increased vascular resistance secondary to unmasking of alpha-mediated vasoconstriction.

Although the existence of beta-adrenergic receptors in the coronary bed is fairly well established, less unanimity exists regarding alpha receptors. The case for alpha receptors has been strengthened by the finding that epinephrine increases coronary vascular resistance in the beta blockaded heart. ${ }^{68-70}$

\section{Effects of Beta-Adrenergic Blockade on Anaesthesia}

At the present time our knowledge of effects of beta blockade upon conduction of anaesthesia is meagre indeed. Fears have been voiced that the combination of cyclopropane, chloroform, trichlorethylene, or ether anaesthesia with betaadrenergic blockade is fraught with peril. ${ }^{53-56,58,71}$ The contention is that absence of sympathetic protection will result in profound myocardial depression.

This attractive hypothesis has been tested against only cyclopropane and halothane to date. Craythorne and Huffington ${ }^{71}$ reported a 47 per cent fall in cardiac output following propranolol administration to dogs anaesthetized with cyclopropane. Systolic blood pressure, myocardial contractility, and stroke volume also declined sharply, whereas peripheral resistance rose in response to beta blockade and unopposed alpha mediated vasoconstriction. No significant response was observed when propranolol was given to dogs anaesthetized with halothane. Of interest is the fact that after beta blockade, haemodynamic observations in the cyclopropane dogs were essentially identical to the control values obtained with halothane. 
Johnstone $e^{53-55}$ reported that pronethalol and propranolol consistently abolished cardiac arrhythmias without adverse effects on arterial blood pressure or digital pulse volume waves during light cyclopropane or light halothane anaesthesia. Carbon dioxide tensions in these patients were not reported but presumably were often elevated because respiration was spontaneous in most cases. An increased level of norepinephrine secondary to hypercarbia would explain why blood pressure was not significantly altered by beta-blockade. In many cases blood pressure actually rose after pronethalol administration. Since unmasking of unopposed alpha receptors by beta blockade produces an increase in peripheral resistance, this could account for the observed maintenance of arterial blood pressure, provided sympathetic activity exceeded the resting state.

We can anticipate increased use of beta blockers during anaesthesia to combat problems associated with sympathetic hyperactivity. Several investigators have used beta blockers successfully in the management of arrhythmias during anaesthesia, ${ }^{1,39,53-58,72}$ mostly due to respiratory acidosis and its attendant sympathetic discharge. There is no doubt about their efficacy as anti-arrhythmic agents. Beta blockade with pronethalol has been shown to elevate the threshold to epinephrineinduced arrhythmias during cyclopropane anaesthesia in dogs to eight times that of controls..$^{73}$

Extensive use of these drugs for the correction of cardiac arrhythmias during anaesthesia appears unnecessary, as pointed out by Johnstone..$^{53,55}$ It seems of dubious value to give a drug which may enhance myocardial depression, in which case at net gain might not be realized. Aetiology of cardiac arrhythmias can almost always be traced to errors in the conduct of anaesthesia, chiefly agent overdosage or improper ventilation. Identification of the aetiology with remedial correction will abolish virtually all arrhythmias arising during anaesthesia.

Beta blockers will likely prove of value in reversing otherwise refractory arrhythmias-for example, paroxysmal atrial tachycardia or digitalis-induced arrhythmias occurring during anaesthesia, and arrhythmias not responding to improved ventilation or lessening of anaesthetic depth.

Propranolol raises the fibrillary threshold in animals cooled to $28-32^{\circ} \mathrm{C} .{ }^{74}$ This finding offers promise of widening the margin of safety in clinical hypothermia, where cardiac arrhythmias are the principal deterrent to deeper hypothermic levels. The benefits of a reduction in arrhythmias, however, might be offset by a rise in peripheral vascular resistance secondary to unmasking of alpha-mediated vasoconstriction. Since epinephrine levels are elevated in hypothermia, ${ }^{75}$ it would be expected that vasoconstriction produced in this manner would be greater than during normothermic states.

Of particular interest to anaesthesiologists are two facets of beta-adrenergic blockade which deserve further investigation: central nervous system effects and local anaesthetic properties. Large doses of pronethalol produce sedative and anti-convulsant effects in mice. ${ }^{76}$ Clinical doses of propranolol apparently do not affect the central nervous system, ${ }^{77}$ although they easily cross the blood brain barrier in mice. ${ }^{78}$

Small animal studies have demonstrated that pronethalol and propranolol are respectively 1.8 and 2.3 times more potent than procaine in producing local 
anaesthesia as measured by intra-dermal wheals. ${ }^{79,80}$ This intriguing observation could be explained by an effect of beta blockade upon ion transfer. Local anaesthetics inhibit active $\mathrm{Na}+$ transport in red blood cells, ${ }^{81}$ and also decrease the permeability to $\mathrm{Na}^{+}$in nerve. ${ }^{82}$ Preliminary studies indicate that propranolol inhibits active $\mathrm{Na}^{+}$transport in the toad bladder. ${ }^{83}$ This effect upon ion transport appeared to be similar to the effect of anaesthetic agents in the same model. ${ }^{84} \mathrm{In}$ contrast, MJ 1999 was found not to interfere with active $\mathrm{Na}^{+}$transfer. Since MJ 1999 appears to be a "pure" beta-adrenergic blocking agent, ${ }^{20}$ this suggests that local anaesthetic effects of pronethalol and propranolol are not a function of beta blockade per se, but rather a separate property, similar (perhaps identical) to their quinidine-like effect on the myocardium. ${ }^{89}$

Beta-adrenergic blocking agents have been advocated for the production of controlled hypotension, ${ }^{55}$ and also to abolish the tachycardia sometimes observed during trimethaphan (Arfonad) administration. ${ }^{85}$ Hypotension resulting from beta-adrenergic blockade is a direct consequence of reduced cardiac output, which is the product of decreased stroke volume and heart rate. Peripheral resistance is usually unchanged, or slightly elevated, secondary to unopposed alpha-mediated vasoconstriction. Thus it seems that peripheral perfusion in this situation would be less than during hypotensive states associated with a reduced peripheral resistance, e.g. ganglionic blockade. Theoretically, then, betaadrenergic blockers are not attractive as a means of inducing controlled hypotension.

Although currently recognized manifestations of beta blockade have been ascertained largely in awake subjects, and may be modified considerably by anaesthetics, one would expect these observations to be useful guides during anaesthesia. Heart rate declines in a linear manner, so that bradycardia is a helpful index of beta blockade. Arterial blood pressure falls as cardiac output decreases. Currently it is believed that peripheral vascular resistance is not affected to any great degree; sympathetic tone seems to be minimal in the resting supine position..$^{20,49}$ Awake subjects in the sitting position, however, display considerably greater sympathetic vascular tone than supine subjects. ${ }^{49}$ Thus, anaesthetized patients who are sitting or prone during surgery may have increased risk imposed upon them by beta blockade.

Since cardiac performance will be the critical determinant of successful anaesthetic management in the presence of beta blockade, it behooves us to glean all of the information we can about cardiac function during anaesthesia. Continuous monitoring of central venous pressure would seem to be essential with the combination of beta blockade and anaesthesia. A rising venous pressure is presumptive evidence that the myocardium is failing and necessitates corrective measures, such as lessening of anaesthetic depth, and should that prove inadequate, administration of a beta-adrenergic agonist, e.g. isoproterenol. ${ }^{86}$

It can be anticipated that concentrations of anaesthetic agents previously tolerated by patients from a circulatory standpoint will be frankly depressant in the presence of beta blockade. It is likely that need for muscular relaxation will require use of relaxants in lieu of depth previously attainable with primary anaesthetic agents. Reversal of relaxants with atropine and neostigmine may 
present disconcerting clinical problems, ${ }^{58}$ and may necessitate departure from previously practised regimens. Administration of atropine to the beta blockaded subject will not be followed by the usual observed cardiac acceleration, because chronotropic activity is beta-mediated. Combined use of atropine and beta blockers will produce a pharmacologically denervated heart, with its own intrinsic rate. ${ }^{87}$

Addition of neostigmine in such a situation should not in itself produce deleterious effects if vagal blockade is complete. Atropine and acetylcholine are thought to be competitive in action; ${ }^{88}$ thus as long as atropine occupies the cholinergic receptors, neostigmine should not induce hazardous bradycardia. If vagal blockade is incomplete, however, the bradycardia produced by neostigmine conceivably could be enhanced because it is unopposed by sympathetic chronotropism. It seems likely that additional bradycardia in such a situation might further compromise an already reduced cardiac output. Until data is available it seems sensible to this reviewer to rely upon artificial ventilation rather than drugs when treating persistent curarization in the presence of beta-adrenergic blockade.

Electrocardiographic monitoring would be helpful, as during any anaesthetic, because it sometimes provides information about the patient which might not otherwise be apparent at the moment. It should be remembered that there is a wide gap between conductive patterns as seen on the E.K.G., and myocardial performance; ${ }^{89}$ cardiac output can be desperately inadequate in the presence of a normal E.K.G. It is possible that beta blockade might obscure deleterious effects of anaesthesia by masking arrhythmias such as premature contractions, which frequently herald cardiac depression in clinical anaesthesia.

Response to an increased cardiac work load ordinarily entails shifting of the ventricular response curve to a higher level of performance ${ }^{90}$ Since this is at least partially dependent upon sympathetic integrity, ${ }^{91,92}$ the heart which is compromised by anaesthesia and beta blockade will not be able to respond in this manner. Thus one would expect decreased tolerance to any factor that increases cardiac work; whether it be haemorrhage ${ }^{86}$ hypoxaemia ${ }^{93}$ metabolic acidosis, ${ }^{86}$ etc.

It is too early to say that the combination of propranolol and certain anaesthetic agents spells disaster, whereas halothane plus propranolol is safe. Fatalities reported with beta blockers have been confined to patients with cardiac failure. Apparently sympathetic support was all that was keeping these sick hearts alive; withdrawal of this support precipitated collapse. We can infer that any anaesthetized patient with critically compromised myocardial reserve will need his sympathetic integrity regardless of anaesthetic agent superimposed.

\section{ToxICITY}

Side-effects of propranolol in doses ranging up to $250 \mathrm{mg}$. daily have been remarkably few. Less than 2 per cent of some 2000 subjects experienced relatively mild side-effects, such as nausea, fatigue, visual disturbances, mild diarrhoea, skin eruptions, and insomnia. ${ }^{94}$ Marked hypotension and cardiac decompensation have occurred in patients with moderately severe cardiac disease. ${ }^{3,7,16,20}$ To avoid 
such catastrophes, Epstein and Braunwald ${ }^{20}$ recommend that in treatment of acute arrhythmias, individual intravenous doses of propranolol not exceed $0.5 \mathrm{mg}$., and that this be repeated every 3 to 4 minutes until the desired effect is attained.

Propranolol is contraindicated in patients with complete atrioventricular block and idioventricular rhythm, because it may abolish all remaining electrical activity. ${ }^{20}$

Administration of beta-adrenergic blocking drugs to asthmatic patients may pose difficulties. Since bronchodilatation is beta-mediated, it would be expected that these drugs increase airway resistance. Indeed, $\mathrm{McNeill}{ }^{95}$ reported that four out of ten asthmatic patients had a sharp fall in the half-second forced expired volume (FEV) after receiving 5-10 $\mathrm{mg}$. propranolol intravenously. Even more surprising was the observation that normal subjects displayed a 50-100 per cent increase in airway resistance as measured by body plethysmography, even though they were asymptomatic.

No adverse bronchoconstrictive effects of combining beta blockers and histamine releasing drugs such as trimetaphan (Arfonad), curare, morphine, etc. have been reported. Although two different mechanisms are operative (histamine acting directly on bronchial musculature), ${ }^{96}$ a greater increase in airway resistance might be anticipated than if either beta blockade or histamine release existed alone.

Another problem recently encountered is hypoglycaemia associated with propranolol administration. Abramson et al..$^{97}$ reported that propranolol dampens the rebound of plasma glucose following insulin tolerance tests, and abolishes the rebound of plasma glycerol. The hypoglycaemia predictable from this observation has been attested to by clinical reports of severe hypoglycaemia, not only in insulin-treated diabetics but also in a post-gastrectomy patient on a restricted carbohydrate diet. ${ }^{98}$

\section{SUMMARY}

Beta-adrenergic receptor blockade may have extensive use in clinical medicine. Interactions between beta-adrenergic blocking drugs and anaesthetic agents may have life-threatening ramifications and sequelae. Physiological responses to anaesthetic agents which stimulate sympatho-adrenal activity may be altered markedly.

Beta-adrenergic blocking agents are contraindicated in patients with atrioventricular block and idioventricular rhythm, because all cardiac electrical activity may be abolished. Relative contraindications include asthma and other broncho-spastic states and conditions predisposing towards hypoglycaemia, e.g. insulin-treated diabetes mellitus.

Anaesthetized patients subjected to beta-adrenergic blockade will have decreased tolerance to any factor that increases cardiac work. Patients with hearts dependent upon sympathetic support for survival will not tolerate removal of that support, regardless of anaesthetic agent superimposed.

Without beta-adrenergic support, evidence of falling cardiac output will be manifested as hypotension and bradycardia. Central venous pressure will rise if the myocardium fails. 


\section{RÉSUMÉ}

Le blocage des récepteurs bêta adrénergiques peut être largement utilisé en clinique. Des actions réciproques entre les médicaments qui bloquent ces récepteurs et les agents anesthésiques peuvent provoquer des séquelles dangereuses pour la vie. Les réponses physiologiques aux agents anesthésiques qui stimulent l'activité sympathico-surrénalienne peuvent être sensiblement affectées.

Les agents qui bloquent les récepteurs bêta-adrénergiques sont contre-indiqués chez les sujets souffrant d'un bloc auriculo-ventriculaire d'un rythme idioventriculaire, parce que toute activité électrique du cœur peut être abolie. Parmi les contre-indications relatives, on relève l'asthme et les autres conditions bronchospasmatiques qui prédisposent à l'hypoglycémie, par exemple les cas de diabète traités à l'insuline.

Chez les malades anesthésiés soumis à un blocage des récepteurs bêtaadrénergiques, on verra apparaître une baisse du débit cardiaque en même temps qu'une hypotension et une bradycardie. La pression veineuse centrale augmentera si le myocarde défaille.

\section{ACKNOWLEDGMENTS}

The author wishes to thank J. S. Gravenstein, M.D., A. H. Anton, Ph.D., T. W. Andersen, M.D., and N. B. Andersen, M.D., for their invaluable counsel and editorial assistance.

\section{REFERENCES}

1. Besterman, E. M. M. \& Frienlander, D. H. Clinical Experiences with Propranolol. Postgrad. Med. J. 41: 526 (1965).

2. Donnhorst, A. C. \& Robinson, B. F. Clinical Pharmacology of a Beta-AdrenergicBlocking Agent (Nethalide). Lancet. 2: 314 (1962).

3. Donnhorst, A. C. Adrenergic Blockade in Cardiovascular Disease. Pharmacol. Rev. 18: 701 (1966).

4. Gillam, P. M. S. \& Prucharo, B. N. C. Propranolol in the Therapy of Angina Pectoris. Amer. J. Cardiol. 18: 366 (1966).

5. Grluam, P. M. S. \& Prichard, B. N. C. Use of Propranolol in Angina Pectoris. Brit. Med. J. 2: 337 (1965).

6. Grant, R. H. E.; Keelan, P.; Kernohan, R. J.; Leonard, J. C.; Nancekievill, L.; \& Sinclarr, K. Multicenter Trial of Propranolol in Angina Pectoris. Am. J. Cardiol. 18: 361 (1966).

7. Hamer, J. \& Sowton, E. Effects of Propranolol on Exercise Tolerance in Angina Pectoris. Am. J. Cardiol. 18: 354 (1966).

8. Rabin, R.; Stables, D. P.; Levin, N. W.; \& Suzman, M. M. The Prophylactic Value of Propranolol in Angina Pectoris. Am. J. Cardiol. 18: 370 (1966).

9. Wolfson, S., Heinle, R. A.; Herman, M. V.; Kemp, H. G.; Sullivan, J. M.; \& Goruln, R. Propranolol and Angina Pectoris. Am. J. Cardiol. 18: 345 (1966).

10. Batr, J. C. J. L. Treatment of Cardiac Arrhythmias in Unanesthetized Patients: Role of Adrenergic Beta Receptor Blockade. Amer. J. Cardiol. 18: 415 (1966).

11. Harris, A. Long Term Treatment of Paroxysmal Cardiac Arrhythmias with Propranolol. Am. J. Cardiol. 18: 431 (1966).

12. Rowlands, D. J.; Howitt, G.; \& Markiman, P. Propranolol (Inderal) in Disturbances of Cardiac Rhythm. Brit. M. J. 1: 891 (1965).

13. Sloman, G.; Robinson, J. S.; \& Mclean, K. Propranolol (Inderal) in Persistent Ventricular Fibrillation. Brit. M. J. 1: 895 (1965).

14. Stock, J. P. P. Beta Adrenergic Blocking Drugs in the Clinical Management of Cardiac Arrhythmias. Am. J. Cardiol. 18: 444 (1966).

15. Stock, J. P. P. \& Dale, N. Beta-Adrenergic Receptor Blockade in Cardiac Arrhythmias. Brit. M. J. 2: 1230 (1963). 
16. Szekely, P.; Jackson, F.; Wynne, N. A.; Vohra, J. K.; Batson, G. A.; \& Dow, W. M. Clinical Observations on the Use of Propranolol in Disorders of Cardiac Rhythm. Am. J. Cardiol. 18: 426 (1966).

17. Turnen, J. R. B. Propranolol in the Treatment of Digitalis-Induced and DigitalisResistant Tachycardias. Am. J. Cardiol. 18: 450 (1966).

18. Vaughn Williams, E. M. \& Sekrya, A. Prevention of Arrhythmias Due to Cardiac Glycosides by Block of Sympathetic $\beta$-Receptors. Lancet. 1: 420 (1963).

19. Cherian, G.; Brockington, I. F.; Shah, P. M.; Oakley, C. M.; \& Goodwin, J. F. Beta Adrenergic Blockade in Hypertrophic Obstructive Cardiomyopathy. Am. J. Cardiol. 18: $481(1966)$.

20. Epstein, S. E. \& Braunwald, E. Beta-Adrenergic Receptor Blocking Drugs: Mechanisms of Action and Clinical Applications. New England J. Med. 275: 1106 (1966).

21. Buist, N. R.; MrJer, F.; \& O'Brien, D. Treatment of a Pheochromocytoma with a BetaAdrenergic Blocking Agent. Arch Dis. Child, 41: 435 (1966).

22. Donnhorst, A. C. \& Laurence, D. R. Use of Pronethalol in Phaeochrome Tumours. Brit. Med. J. 2: 1250 (1963).

23. Prichard, B. N. C. \& Ross, E. J. Use of Propranolol in Conjunction with Alpha Receptor Blocking Drugs in Pheochromocytoma. Am. J. Cardiol. 18: 394 (1966).

24. Paterson, J. W. \& Dollery, C. T. Effect of Propranolol in Mild Hypertension. Lancet. 2: $1148(1966)$.

25. Prichard, B. N. C. \& Gillam, P. M. S. Propranolol in Hypertension. Am. J. Cardiol. 18: 387 (1966).

26. Brewster, W. R.; Isaacs, J. P.; \& Andersen, T. W. Depressant Effect of Ether on Myocardium of Dog and Its Modification by Reflex Release of Epinephrine and Norepinephrine. Am. J. Physiol. 175: 399 (1953).

27. Price, H. L.; Linde, H. W.; Jones, R. E.; Black, G. W.; \& Price, M. L. SympathoAdrenal Responses to General Anesthesia in Man and Their Relation to Hemodynamics. Anesthesiology. 20:563 (1959).

28. Langley, J. N. On the Reaction of Cells and of Nerve-Endings to Certain Poisons, Chiefly as Regards to the Reaction of Striated Muscle to Nicotine and to Curari. J. Physiol. (London). 33: 374 (1905).

29. Dale, H. H. On Some Physiological Actions of Ergot. J. Physiol. (London), 34: 163 (1906).

30. Ahlquist, R. P. A Study of Adrenotropic Receptors. Am. J. Physiol. 153: 586 (1948).

31. Moran, N. C. \& Perkins, M. E. Adrenergic Blockade of the Mammalian Heart by a Dichloro Analogue of Isoproterenol. J. Pharmacol. Exper. Therap. 124: 223 (1958).

32. Furcirgott, R. F. The Receptors for Epinephrine and Norepinephrine (Adrenergic Receptors). Pharmacol. Rev. 11: 429 (1959).

33. Powell, C. E. \& Slater, I. H. Blocking of Inhibitory Adrenergic Receptors by a Dichloro Analog of Isoproterenol. J. Pharmacol. Exper. Therap. 122: 480 ( 1958).

34. Dresel, P. E. Blockade of Some Cardiac Actions of Adrenaline by Dichloroisoproterenol. Canad. J. Biochem. Physiol. 38: 375 (1960).

35. Blıck, J. W. \& Stephenson, J. S. Pharmacology of a New Adrenergic Beta-ReceptorBlocking Compound (Nethalide). Lancet. 2: 311 (1962).

36. Paget, G. E. Carcinogenic Action of Pronethalol. Brit. M. J. 2: 1266 (1963).

37. Black, J. W.; Crowther, A. F.; Shanks, R. G.; Smith, L. H.; \& Dornhohst, A. C. A New Adrenergic Beta-Receptor Antagonist. Lancet. 1: 1080 (1964).

38. Shanks, R. G. The Pharmacology of Beta Sympathetic Blockade. Am. J. Cardiol. 18: $308(1966)$.

39. Ariëns, E. J. \& Simonis, A. M. A Molecular Basis for Drug Action. J. Pharm. \& Pharmacol, 16: 137 (1964).

40. Shanks, R. G. The Effect of Propranolol on the Cardiovascular Responses to Isoprenaline, Adrenaline and Noradrenaline in the Anaesthetized Dog. Brit. J. Pharmacol. 26: 322 (1966).

41. Flacke, J. W.; Osgood, P. F.; \& Bendixen, H. H. Actions of Propranolol and Isoproterenol in Blocked Dogs. Fed. Proc. 25: 471 (1966).

42. MaHon, W. A. The Hemodynamic Effects of Beta Adrenergic Blockade in Man. Clin. Res. Proc. 13: 213 (1965).

43. Nakano, J. \& Kusakari, T. Effect of Beta Adrenergic Blockade on the Cardiovascular Dynamics. Am. J. Physiol. 210: 833 (1966).

44. Black, J. W.; Duncan, W. A. M.; \& Shanks, R. G. Comparison of Some Properties of Pronethalol and Propranolol. Brit. J. Pharmacol. 25: 577 ( 1965 ). 
45. Morax, N. C. Pharmacological Characterization of Adrenergic Receptors. Pharmacol. Rev. 18: 503 (1966).

46. Sowton, E. \& Hamer, J. Hemodynamic Changes after Beta Adrenergic Blockade. Am. J. Cardiol. 18: 317 (1966).

47. Sonnenblick, E. H.; Braunwald, E.; Williams, J. F., JR.; \& Glick, G. Effects of Exercise on Myocardial Force-Velocity Relations in Intact Unanesthetized Man: Relative Roles of Changes in Heart Rate, Sympathetic Activity and Ventricular Dimensions. J. Clin. Invest. 44: 2051 (1965).

48. Chamberlain, D. A. Effects of Beta Adrenergic Blockade on Heart Size. Am. J. Cardiol. 18: 321 (1966).

49. Robinson, B. F.; Epstein, S. E.; Beiser, G. D.; \& Braunwald, E. Control of Heart Rate by the Autonomic Nervous System: Studies in Man on the Interrelation between Barareceptor Mechanisms and Exercise. Cir. Res. 19: 400 (1966).

50. Epstein, S. E.; Robinson, B. F.; Kahler, R. L.; \& Braunwald, E. Effects of BetaAdrenergic Blockade on the Cardiac Response to Maximal and Submaximal Exercise in Man. J. Clin. Invest. 44: 1745 (1965).

51. MacDonald, H. R.; Sapru, R. P.; Taylor, S. H.; \& Donald, K. W. Effect of Intravenous Propranolol on the Systemic Circulatory Response to Sustained Handgrip. Amer. J. Cardiol. 18: 333 (1966).

52. Brick, I.; Glover, W. E.; Hutchison, K. J.; \& Roddie, I. C. Effects of Propranolol on Peripheral Vessels in Man. Am. J. Cardiol. I8: 329 (1966).

53. Johnstone, M. Beta-Adrenergic Blockade with Pronethalol during Anaesthesia. Brit. J. Anaesth. 36: 224 (1964).

54. Johnstone, M. Propranolol (Inderal) during Halothane Anaesthesia. Brit. J. Anaesth. 38: 516 (1966).

55. Johnstone, M. Propranolol in Anesthesia. Am. J. Cardiol. 18: 479 (1966).

56. Payne, J. P. \& Senfield, R. M. Pronethalol in the Treatment of Ventricular Arrhythmias during Anaesthesia. Brit. M. J. 1: 603 (1964).

57. Sharma, P. L. Effect of Propranolol on Catecholamine-Induced Arrhythmias during Nitrous Oxide-Halothane Anaesthesia in the Dog. Brit. J. Anaesth. 38: 871 (1966).

58. VetTen, K. B. \& KüNDIG, H. Clinical Observations on Some Pharmacological Properties of Pronethalol, a Beta-Receptor Blocker with Special Reference to Anaesthesia. Med. Proc. 11: 417 (1965).

59. SNow, P. J. D. Effect of Propranolol in Myocardial Infarction. Lancet. 2: 551 (1965).

60. Stephen, S. A. Propranolol in Acute Myocardial Infarction. A Multicentre Trial. Lancet. 2: 1435 (1966).

61. Benfey, B. G. \& VArma, D. R. Antisympathomimetic and Antifibrillatory Effects of Pronethalol and Propranolol. Brit. J. Pharmacol. 26: 3 (1966).

62. Rouse, W. Effects of Propranolol and Ouabain on the Conducting System of the Heart in Dogs. Am. J. Cardiol. 18: 406 (1966).

63. Sekiya, A. \& Vaughn Williams, E. M. The Effects of Pronethalol, Dichloroisoprenaline and Disopyramide on the Toxicity to the Heart of Ouabain and Anaesthetics. Brit. J. Pharmacol. 21: 462 (1963).

64. - - A Comparison of the Antifibrillatory Actions and Effects on Intracellular Cardiac Potentials of Pronethalol, Disopyramide and Quinidine. Brit. J. Pharmacol. 21: 473 (1963).

65. Vaughn Williams, E. M. Mode of Action of Beta Receptor Antagonists on Cardiac Muscle. Am. J. Cardiol. 18: 399 (1966).

66. Nickerson, M. \& Nomaguchr, G. M. Mechanism of Dibenamine Protection against Cyclopropane-Epinephrine Cardiac Arrhythmias. J. Pharmacol. Exper. Therap. 95: 1 (1949).

67. Eckstein, R. W; Stroud, M.; Eckel, R.; Dowling, C. V.; \& Pritchard, W. H. Effects of Control of Cardiac Work upon Coronary Flow and $\mathrm{O}_{2}$ Consumption after Sympathetic Nerve Stimulation. Am. J. Physiol. 163: 539 (1950).

68. Parhatt, J. R. \& Grayson, J. Myocardial Vascular Reactivity after Beta-Adrenergic Blockade. Lancet. 1: 338 (1966).

69. GaAl, P. G.; Kattus, A. A.; Kolin, A.; \& Ross, G. Effects of Adrenaline and Noradrenaline on Coronary Blood Flow before and after Beta-Adrenergic Blockade. Brit. J. Pharmacol. 26: 713 (1966).

70. Pitr, B.; Elitot, E. C.; \& GregG, D. E. Hemodynamic Effects of Catecholamines on the Coronary Circulation in the Unanesthetized Dog. Fed. Proc. 25: 401 (1966).

71. Craythorne, N. W. B. \& Huffington, P. E. Effects of Propranolol on the Cardiovascular Responses to Cyclopropane and Halothane. Anesthesiology. 27: 580 (1966). 
72. Hellewell, J. \& Potts, M. W. Propranolol and Ventricular Arrhythmias with Halothane. Anaesthesia. 20: 269 (1965).

73. Katz, R. L. Effect of Alpha and Beta Adrenergic Blocking Agents on CyclopropaneCatecholamine Cardiac Arrhythmias. Anesthesiology. 26: 289 (1965).

74. Szekners, L.; PAPP, J.; \& Förster, W. The Action of Adrenergic $\beta$-Receptor Blocking Agents on Susceptibility to Cardiac Arrhythmias in Hypothermia and Hypoxia. Experientia. 21: 720 (1965).

75. Anton, A. H.; Gravenstein, J. S.; \& Wheat, M. W., JR. Extracorporeal Circulation and Endogenous Epinephrine and Norepinephrine in Plasma, Atrium and Urine in Man. Anesthesiology, 25: 262 (1964).

76. Leszkovsky, G. \& Tardos, L. Some Effects of Propranolol on the Central Nervous System. J. Pharm. Pharmacol. 10: 518 (1965).

77. Granville-Grossman, K. L. \& Turner, P. The Effect of Propranolol on Anxiety. Lancet. 1: 788 ( 1966 ).

78. Clark, W. G. \& Vivonia, C. A. Central and Peripheral $\beta$-Receptor Effects of Four $\beta$-Adrenergic Blocking Drugs. Fed. Proc. 26: 402 (1967).

79. Gill, E. W. \& Vaughn Williams, E. M. Local Anaesthetic Activity of the Beta Receptor Antagonist, Pronethalol. Nature. 201: 199 (1964).

80. Morales-Aquilera, A. \& Vaughn Williams, E. M. The Effects on Cardiac Muscle of $\beta$-Receptor Antagonists in Relation to Their Activity as Local Anaesthetics. Brit. J. Pharmacol. 24: 332 (1965).

81. Andersen, N. B. \& Gravenstein, J. S. Effects of Local Anesthetics on Sodium and Potassium in Human Red Cells. J. Pharmacol. Exper. Therap. 147: 40 (1965).

82. Shanes, A. M. Electrochemical Aspects of Physiological and Pharmacological Action in Excitable Cells. Part I. The Resting Cell and Its Alteration by Extrinsic Factors. Pharmacol. Rev, 10: 59 (1958).

83. Anderson, N. B. Personal communication.

84. ANDERSEN, N. B. Effect of General Anesthetics on Sodium Transport in the Isolated Toad Bladder. Anesthesiology. 27: 304 (1966).

85. Helleweld, J. \& Potts, M. W. Propranolol during Controlled Hypotension. Brit. J. Anaesth. 38: 794 (1966).

86. Vickers, M. D. Adrenergic Drugs and Their Antagonists in Anaesthesia. Brit. J. Anaesth, 38: 728 (1966).

87. Jose, A. D. Effect of Combined Sympathetic and Parasympathetic Blockade on Heart Rate and Cardiac Function in Man. Am. J. Cardiol. 18: 476 (1966).

88. Goodman, L. S. \& Gllman, A. The Pharmacological Basis of Therapeutics. 3rd ed., New York: Macmillan (1965), p. 523.

89. Mazzia, V. D. B.; Eli.is, C. H.; Siegal, H.; \& Henshey, S. G. The Electrocardiograph as a Monitor of Cardiac Function in the Operating Room. J.A.M.A. 198: 103 (1966).

90. Sarnoff, S. J. \& Berglund, E. Ventricular Function: 1. Starling's Law of the Heart Studied by Means of Simultaneous Right and Left Ventricular Function Curves in the Dog. Circulation. 9: 706 (1954).

91. Eckstein, J. W. \& Horslex, A. W. The Effects of Reduced Cardiac Sympathetic Tone on Myocardial Function. J. Clin. Invest. 40: 555 (1961).

92. Sannoff, S. J. Certain Aspects of the Role of Catecholamines in Circulatory Regulation. Am. J. Cardiol. 5: 579 (1960).

93. Ruchardonon, D. W; Kontos, H. A.; Raper, A. J.; \& Patterson, J. L., Jr. Modification by $\beta$-Adrenergic Blockade of Circulatory Responses to Acute Hypoxia in Man. J. Clin. Invest. 46: 77 (1967).

94. Stephen, S. A. Unwanted Side Effects of Propranolol. Am. J. Cardiol. 18: 463 (1966).

95. McNeill, R. S. \& Ingram, C. G. Effect of Propranolol on Ventilatory Function. Am. J. Cardiol. 18: 473 (1966).

96. Goodman, L. S. \& Gilman, A. The Pharmacological Basis of Therapeutics. 3rd ed., New York: Macmillan (1965), p. 618.

97. Abramson, E. A.; Ankx, R. A.; \& Woeber, K. A. Effects of Propranolol on the Hormonal and Metabolic Responses to Insulin-induced Hypoglycaemia. Lancet. 2: 1386 (1966).

98. Kotler, M. N.; Berman, L.; \& Rubenstein, A. H. Hypoglycaemia Precipitated by Propranolol. Lancet. 2: 1389 (1966).

99. Kako, K.; Krayenuüht, H. P.; Lüthy, E.; \& Hegglin, R. Cardiovascular Effects of Catecholamines in Dogs before and after Beta-Adrenergic Blockade. Arch. Pharm. Exp. Path. 246: 297 (1964).

100. Vaughn Williams, E. M. \& Szekeres, L. A Comparison of Tests for Anti-Fibrillatory Action. Brit. J. Pharmacol. 17: 424 (1961). 